\title{
Nepalese Tax Structure: An Analytical Perspective
}

\author{
Madhav Khanal, M. Phil \\ Lecturer \\ Department of Education and Social Science \\ Janamaitri Multiple Campus, Kuleshwar Kathmandu, Nepal \\ Email:madhavakhanal@gmail.com
}

Peer Reviewed by: Prof. Dr. R. K.Shah

Prof. Dr. Shree Ram Paudel

\begin{abstract}
Tax is the major source of revenue for the government, and development of any country's economy largely depends on the tax structure it has adopted. A Tax structure which facilitates easy business and leaves no chance for tax evasion brings prosperity to a country's economy. On the other hand, tax structure that has provisions for tax evasion and the one which does not facilitate ease of doing business shows down the economic growth. Nepal has a well-developed tax structure. The power to levy taxes and duties is distributed among the three tiers of the Government, in accordance to the constitutional provisions. Nepali tax system has gone through many reforms but still it is very far from being an ideal one. Many problems like tax evasion, reliance on indirect taxes, black money and existence of parallel economy show that Nepali tax system requires some major reforms in the future ahead to address all this problem. This study is purely based on secondary data. Various figures are obtained from different sources of the government of Nepal. It is seen that there is major dependence on indirect taxes than the direct taxes.
\end{abstract}

Keywords: Direct Taxes, Indirect Taxes, Tax Structure of Nepal, Taxation, Tax Collection, Tax Evasion.

\section{Background}

The political history of Nepal shows the existence of various forms of tax since the ancient period (Dahal, 2004). Taxes were imposed as per the Shastras, Kautilya Nitee, Manu Smriti, Yagyavalkya Smriti, during the ancient period. Kautilya, Yagyavalkya and 
Manu were great philosophers of eastern civilization during ancient time. The principles and philosophy propounded by them were known as Kautilya Nitee, Yagyavalkya Smriti and Manu Smriti. Kautilya was also popularly known as Chanakya and his principle as Chanakyaniti. Chanakya was an advisor of the first Maurya Emperor Chandragupta Maurya, who is said to have ruled India from $320 \mathrm{BC}$ to $298 \mathrm{BC}$. The main principle of taxation at that time was to impose tax without hampering the taxpayers (Kandel, 2011). According to the Shastras, taxes were imposed in a manner so that one would collect honey from the beehives or get milk from the udder of a milk cow.

Tax was collected at that time to launch various government programme. According to Kautilya, "the launching of all programme depends first and foremost on the treasury." The Licchhavi rulers entered Nepal around the mid of the fifth century B.C. from the Republic of Vaisali (presently northern part of the state of Bihar of India) and ruled Kathmandu Valley till 750 B.C. They imposed three forms of Karas (taxes): Bhaga, tax on agriculture, Bhoga, tax on livestock and Kara, tax on trade. Matsya Kara (imposed on fishing), Palabdu Kara (imposed on onion and garlic), Malla Kara (imposed on wrestling), Goyuddha Kara (imposed on bull fighting), and Sin Kara (imposed on firewood), were some of the taxes of that time. Ansubarma, one of the Lichchavi kings, imposed water tax and religious monument repair tax. At that time, a tax on the income of the farmers from agriculture was imposed at the rate of $1 / 6,1 / 8$ and $1 / 12$ shares of crop production depending on the land quality (Dahal, 2004).

Although, the taxes were collected in various forms in ancient era, the history of tax is not very old in Nepal. The idea of introducing income tax in Nepal originated in the early 1950s when a multi- party democratic political system was introduced. In 1951, the government declared its intention to levy income tax through the budget speech.

The first elected government in 1959 finally introduced Business Profit and Salaries Tax Acts, 1960 in Nepal. At that time, income tax was levied only on business profit and salaries. After about three years' experience of income tax, the government replaced the prevailing Tax Act by Income Tax Act 1962. The coverage was extended in the Act. In 1974, Income Tax Act, 1974 was enacted. The Act categorized income source into five groups, a) agriculture, b) industry trade, profession or occupation, c) remuneration, d) house and compound rent, e) other sources. However, agriculture income was kept outside the income tax net except few years through the finance Acts.

To enhance revenue mobilization through effective revenue collection procedure for the economic development of the nation and to amend and integrate the laws relating to income tax, the Parliament of Nepal enacted Income Tax Act, 2002. This act replaced Income Tax Act, 1974, which was amended eight times and existed for a period of 28 years. The Government of Nepal framed Income Tax Rules 2059 in 2059 which clarified the Act. Nepal is adopting various strict policies to collect income tax. 
The concept of VAT in Nepal was introduced in early 1990s. Government of Nepal indicated its intention to introduce VAT in the Eighth Plan, subsequently the Finance Minister declared to introduce a two- tier sales tax system to establish the base of implementing VAT from the FY 1992/93. A VAT task force was termed in 1993 under the financial assistance of USAID in order to make necessary preparation for the introduction of VAT. The tax force was given the responsibility of preparing the draft of VAT legislation.

In 1995 the Parliament of Nepal enacted "Value Added Tax Act - 1995 (2052)", Subsequently VAT regulation was prepared in 1996; the Act was passed in 1997. Its implementation was delayed due to political instability and strong opposition from business community. VAT with single rate of 10 percent was fully implemented with its effect from 16 November, 1997. It replaced sales tax, hotel tax, contract tax and entertainment tax. VAT has been justified in the light of government fiscal imbalance and need for extra revenue mobilization through an efficient tax system. The government of Nepal increased VAT from 10 percent to 13 percent effective from 15 February, 2004. A value-added tax (VAT) is a consumption tax placed on a product whenever value is added at each stage of the supply chain, from production to the point of sale. The amount of VAT that the user pays is on the cost of the product, less any of the costs of materials used in the product that have already been taxed.

Tax, is the payment we make to the government, for a goods and service. It is this money that government uses for all the functions it is expected to deliver in various like military, infrastructure- economic and social, basic amenities and welfare.

In Nepal, the taxes are classified in to two types, direct taxes and indirect taxes.

Direct Taxes are those which are paid directly by the individual or organization to the imposing authority. They are levied on income and profits

Indirect Taxes are those which are not paid directly by the individual or organization to the imposing authority. They are levied on goods and services and not on income and profits.

\section{Direct Taxes}
(a) Corporation tax
(b) Taxes on income
(c) Estate duty
(d) Interest tax
(e) Wealth tax
(f) Gift tax
(g) Land revenue
(h) Agricultural tax
(i) Hotel receipts tax
(j) Expenditure tax and
(k) Other's

\section{Indirect Taxes}
(a) Customs
(b) Union excise duties
(c) Service tax
(d) State excise duty 
(e) Taxes on vehicle

(g) Stamp and registration fees

(i) Taxes on goods and passengers

(k) Taxes on purchase of sugarcane and (f) General sales tax

(h) Entertainment tax

(j) Taxes and duties on electricity

(1) others

\section{Statement of the Problem}

Nepalese taxation structure has gone through many reforms and still it is very far from being an ideal taxation structure. Many problems like tax evasion, reliance on indirect taxes, black money, existence of parallel economy show that Nepali tax system requires some major reforms in the future to address these problems.

\section{Objectives}

- To study the tax structure of Nepal,

- To identify the different taxes collected,

- To identify the amount incurred on collection of taxes,

- To identify the amount of revenue.

\section{Need of the Study}

The development of any country's economy depends directly on the Country's Taxation Structure. A tax structure that facilitates ease of doing business and having no chance for tax evasion brings prosperity to a country's economy. On the other hand, tax structure which has loopholes facilitating tax evasion and the one which does not facilitate ease of doing business slows down the growth of country's economy. Therefore, as tax structure plays an important role in country's development. There is always need for the study of the taxation structure to make the tax system simpler that earlier.

\section{Review of Literature}

\section{Income Taxation}

Not surprisingly, one fundamental issue in income taxation has been the concept of 'income'. Haig (1921) defined income as 'the money-value of the net accretion of economic power between two points in time'. Simons (1938) definition was that personal income, 'may be defined as the algebraic sum of (a) the market value of rights exercised in consumption and (b) the change in the value of the store of property rights between the beginning and end of the period in question. Hicks (1974) defined income as the 'maximum amount of money which the individual can spend this week, and still be able to spend the same amount in real terms in each ensuing week'.

There are two aspects to wealth taxation - taxes on the transfer of wealth, often on death, and net wealth taxes. There will be dealt with, in turn, and the case for both of them includes efficiency and equity arguments. 
It has been argued that death duties or inheritance taxes should include transfers made during life since otherwise the rich could avoid such taxation by passing on their wealth before they died. However, Whalley (1974) found evidence that the rich did not find this a good reason to give their wealth away. Possibly therefore such taxes might be considered to be voluntary taxes paid by those who disliked their relatives even more than they disliked paying tax. The UK attempt to do this - the ill-fated Capital Transfer Tax was introduced in 1975 constantly modified and finally repealed in 1986. It could not be considered a success (Sutherland, 1984). The role of such taxes has also been considered by Aaron and Munnell (1992).

Economic research has contributed in a number of ways to the study of corporate taxation - for instance whether, corporation tax should be a separate form of taxation or integrated with personal income tax - as discussed for example by Musgrave and Musgrave (1989). Mintz (1995) provides a more recent survey on corporate taxation which he suggested might be the most well-studied tax found throughout the world.

\section{Value Added Tax}

Shoup (1969), considered Value Added Tax as the latest and probably the final stage in historical development of general sales tax imposed on the value added by the business firm. He explained VAT as the difference between sales proceeds and cost of materials etc purchased from others firms, which is the tax base of VAT. He further added, a firm adds value added by processing or handling these purchases items with its labor force and its own machinery, bulking or other capital goods.

While talking about the types of VAT and its practicability i.e. GNP, income and consumption Musgrave and Musgrave (1976), in their book "Public Finance, Theory and Practices" had preferred the latest type of VAT as more applicable and reliable one for both efficiency and quality which was similar to the retail sales tax and seemed to be more practical for poor countries. Likewise, the invoice method for calculation was more preferable and has the advantage of the value-added approach.

\section{Excise Duties}

In Nepal in 1955 customs and excise department were established. In 1966, a separate excise department came into existence. Presently, there are three sources of excise revenue: (a) excise from contract tax, (b) excise from agricultural production, and (c) excise from industrial production. The significant position of excise revenue in both developed and developing countries is of vital interest.

In a study of 82 developing and industrial countries, the contribution of excise duties was found to be nearly 25 percent of the total revenue (Cnosser, 1974). 


\section{Research Methodology}

This Research paper is purely based on secondary data. Various figures are obtained from the different sources of government of Nepal.

\section{Analysis of Nepalese Tax Structure}

Like in any other country, the government of Nepal needs revenue to conduct the functions of an independent country. A modern democratic government has to perform various social welfare programs, besides its regular activities. For this purpose, government collects revenue. These are tax revenue and non-tax revenue. These both sources are subjects to non-repayment and their sum constitutes the government or public revenue. For an under-developed country like Nepal, the role of taxation in the process of economic development is considerably significant. In this way, tax structure stands as a mirror of the government as well as ability of the people to pay the tax, is the major factor of designing the tax structure. In this respect, the tax structure has vital role in development.

Government collects the revenue from different sources. Basic source of the Government Revenue is classified into tax and non-tax revenue. Tax revenue has been playing dominant role in our total revenue structure. Nepalese economy is characterized by a low revenue performance in contrast to the growing public expenditure. Revenue growth is not maintaining a pace with the expenditure growth. The composition of the government revenue and total tax from FY 1974/75 to 2016/17 is presented in figure 1 .

Figure 1 : Government Revenue and Total Tax (1974/75 to 2016/17)

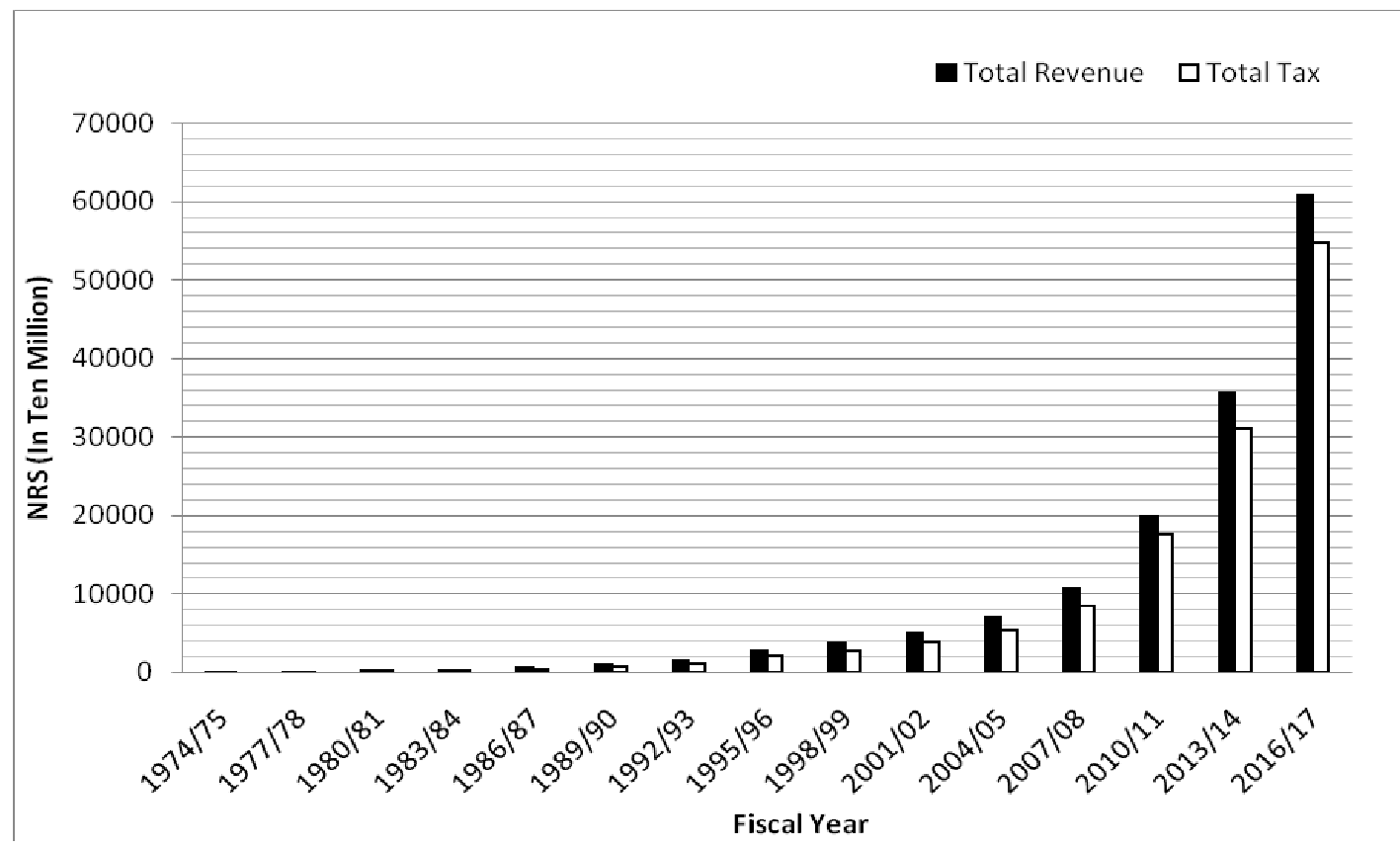

Source: Economic Survey, FY 2016/17 and various years' budget 
Figure 1 shows that during the study period there has simultaneous increase in total tax revenue, direct tax and indirect tax revenue in absolute term. In FY 1974/75 the amount of tax revenue was NRs 841.7 million and in FY2016/2017 the amount of tax revenue is NRs 547486.4 million and the total revenue was NRs. 1008.4 million in FY 1974/75and in FY 2016/2017 the amount of total revenue is NRs. 609180 million.

\section{Share of Tax and Non-tax Revenue in Total Revenue}

Nepal is one of the developing countries so in Nepal, the contribution of tax revenue used to be almost 80 percent and non-tax revenue almost 20 percent and ratio of Total Revenue to real GDP is 6 to 24 percentages. The shares of tax revenue and non-tax revenue in total revenue and real GDP have been shown in the following table:

Table 1: Share of Tax and Non-tax Revenue in Total Revenue

\begin{tabular}{|c|c|c|c|c|c|c|c|c|}
\hline \multirow{2}{*}{$\begin{array}{l}\text { Fiscal } \\
\text { Year }\end{array}$} & \multicolumn{2}{|c|}{ Tax Revenue } & \multicolumn{2}{|c|}{ Non-Tax Revenue } & \multirow{2}{*}{$\begin{array}{c}\text { Total } \\
\text { Revenue } \\
\text { NRs. in Ten } \\
\text { Million }\end{array}$} & \multirow{2}{*}{$\begin{array}{c}\text { Real GDP } \\
\text { (Current } \\
\text { Price) } \\
\text { NRs. in Ten } \\
\text { Million }\end{array}$} & \multirow{2}{*}{$\begin{array}{l}\text { Percent } \\
\text { age in Total } \\
\text { Revenue to } \\
\text { GDP }\end{array}$} & \multirow{2}{*}{$\begin{array}{c}\text { Correlation } \\
\text { in TR to } \\
\text { GDP }\end{array}$} \\
\hline & $\begin{array}{c}\text { NRs. in Ten } \\
\text { Million }\end{array}$ & Percentage & $\begin{array}{l}\text { NRs. } \\
\text { in Ten } \\
\text { Million }\end{array}$ & Percentage & & & & \\
\hline $1974 / 75$ & 84.2 & 83.50 & 16.64 & 16.50 & 100.84 & 1660.1 & 6.07 & \multirow{20}{*}{0.979} \\
\hline $1975 / 76$ & 90.86 & 81.59 & 20.5 & 18.41 & 111.36 & 1739.4 & 6.40 & \\
\hline 1976/77 & 110.01 & 83.16 & 22.28 & 16.84 & 132.29 & 1728 & 7.65 & \\
\hline $1977 / 78$ & 124.39 & 78.62 & 33.82 & 21.38 & 158.21 & 1972.7 & 8.02 & \\
\hline $1978 / 79$ & 147.68 & 81.51 & 33.49 & 18.49 & 181.17 & 2612.8 & 6.93 & \\
\hline $1979 / 80$ & 153.88 & 81.42 & 35.12 & 18.58 & 189 & 2335.1 & 8.09 & \\
\hline $1980 / 81$ & 203.57 & 84.15 & 38.35 & 15.85 & 241.92 & 2553 & 9.47 & \\
\hline $1981 / 82$ & 221.13 & 82.53 & 46.82 & 17.47 & 267.95 & 3098.8 & 8.64 & \\
\hline $1982 / 83$ & 242.61 & 85.23 & 42.05 & 14.77 & 284.66 & 3382.1 & 8.41 & \\
\hline $1983 / 84$ & 273.7 & 80.28 & 67.23 & 19.72 & 340.93 & 3929 & 8.67 & \\
\hline $1984 / 85$ & 315.12 & 80.45 & 76.56 & 19.55 & 391.68 & 4658.7 & 8.40 & \\
\hline $1985 / 86$ & 365.93 & 78.79 & 98.52 & 21.21 & 464.45 & 5573.4 & 8.33 & \\
\hline $1986 / 87$ & 437.17 & 73.19 & 160.17 & 26.81 & 597.34 & 6386.4 & 9.35 & \\
\hline $1987 / 88$ & 575.28 & 78.27 & 159.76 & 21.73 & 735.04 & 7690.6 & 9.55 & \\
\hline $1988 / 89$ & 628.72 & 80.81 & 149.35 & 19.19 & 778.07 & 8927 & 8.71 & \\
\hline $1989 / 90$ & 728.39 & 78.21 & 202.89 & 21.79 & 931.28 & 10341.6 & 9.00 & \\
\hline 1990/91 & 817.63 & 76.20 & 255.32 & 23.80 & 1072.95 & 12037 & 8.91 & \\
\hline $1991 / 92$ & 987.56 & 73.08 & 363.71 & 26.92 & 1351.27 & 14948.7 & 9.03 & \\
\hline $1992 / 93$ & 1166.25 & 76.99 & 348.59 & 23.01 & 1514.84 & 17149.2 & 8.83 & \\
\hline 1993/94 & 1537.15 & 78.50 & 420.94 & 21.50 & 1958.09 & 19927.2 & 9.82 & \\
\hline
\end{tabular}




\begin{tabular}{|c|c|c|c|c|c|c|c|}
\hline $1994 / 95$ & 1966 & 79.90 & 494.51 & 20.10 & 2460.51 & 21917.5 & 11.22 \\
\hline $1995 / 96$ & 2166.8 & 77.68 & 622.51 & 22.32 & 2789.31 & 24891.3 & 11.20 \\
\hline $1996 / 97$ & 2442.43 & 80.41 & 594.92 & 19.59 & 3037.35 & 28051.3 & 10.82 \\
\hline $1997 / 98$ & 2593.98 & 78.75 & 699.81 & 21.25 & 3293.79 & 30084.5 & 10.94 \\
\hline $1998 / 99$ & 2875.29 & 77.19 & 849.84 & 22.81 & 3725.13 & 34203.6 & 10.89 \\
\hline $1999 / 00$ & 3315.21 & 77.29 & 974.16 & 22.71 & 4289.37 & 37948.8 & 11.30 \\
\hline $2000 / 01$ & 3886.5 & 79.49 & 1002.88 & 20.51 & 4889.38 & 44151.9 & 11.07 \\
\hline $2001 / 02$ & 3933.06 & 77.96 & 1111.6 & 22.04 & 5044.66 & 45944.3 & 10.98 \\
\hline $2002 / 03$ & 4089.6 & 74.99 & 1364.29 & 25.01 & 5453.89 & 49223.1 & 11.08 \\
\hline $2003 / 04$ & 4817.3 & 77.29 & 1415.8 & 22.71 & 6233.1 & 53674.9 & 11.61 \\
\hline $2004 / 05$ & 5410.47 & 77.16 & 1601.8 & 22.84 & 7012.27 & 58941.2 & 11.89 \\
\hline $2005 / 06$ & 5743.04 & 79.45 & 1485.15 & 20.55 & 7228.19 & 65408.4 & 11.05 \\
\hline $2006 / 07$ & 7112.67 & 81.09 & 1658.54 & 18.91 & 8771.21 & 72782.7 & 12.05 \\
\hline $2007 / 08$ & 8515.55 & 79.12 & 2246.7 & 20.88 & 10762.25 & 81565.8 & 13.19 \\
\hline $2008 / 09$ & 11705.19 & 81.58 & 2642.26 & 18.42 & 14347.45 & 98827.2 & 14.51 \\
\hline $2009 / 10$ & 15978.53 & 89.77 & 1820.56 & 10.23 & 17799.09 & 119277.4 & 14.92 \\
\hline $2010 / 11$ & 17722.72 & 89.34 & 2114.87 & 10.66 & 19837.59 & 136695.4 & 14.51 \\
\hline $2011 / 12$ & 21172.18 & 86.64 & 3265.12 & 13.36 & 24437.3 & 152734.4 & 16.00 \\
\hline $2012 / 13$ & 25961 & 87.52 & 3703.2 & 12.48 & 29664.2 & 169501.1 & 17.50 \\
\hline $2013 / 14$ & 31180 & 87.38 & 4504 & 12.62 & 35684 & 196454 & 18.16 \\
\hline $2014 / 15$ & 35594.29 & 87.70 & 4990.35 & 12.30 & 40584.64 & 213020 & 19.05 \\
\hline $2015 / 16$ & 42109.66 & 87.37 & 6086.5 & 12.63 & 48196.17 & 225316.31 & 21.39 \\
\hline $2016 / 17$ & 54748.64 & 89.87 & 6169.36 & 10.13 & 60918 & 264259.53 & 23.05 \\
\hline $2017 / 18$ & 65949.13 & 92.37 & 7274.3 & 7.63 & 73223.44 & 300724.62 & 24.34 \\
\hline & & & & & & &
\end{tabular}

Source: Economic Survey, FY 2016/17 and various years' budget.

Table 1 shows that in composition of total revenue, tax revenue has dominant role because the table shows in FY 1974/75 total revenue NRs.10.084 billion where 83.5 percent is contributed by tax revenue and remaining by not-tax revenue. Tax revenue is 92.37 percent and not-tax revenues 7.63 percent in last FY 2017/18. This scenario indicates that the role of tax revenue is very important in revenue mobilization of Nepal to meet the growing Government expenditure. The total tax revenue in FY 1974/75 was NRs. 842 million, which was increasing every year and reached to NRs 65949.13 million in fiscal year FY 2017/18. The highest contribution of tax revenue to total revenue was 92.37 percent in FY 2017/18 and lowest contribution was 73.08 percent in FY 1991/92. It is clear that tax revenue has dominant role in Nepalese economy. 
The percentage in total revenue to GDP was 6.07 in FY 1974/75 and it is 24.34 in FY 2017/18. This scenario indicates that the percentage of total revenue to real GDP increasing every year, and it is strongly correlated.

\section{Composition of Tax Revenue}

The composition of tax revenue from FY 1974/75 to FY 2017/18 was presented in the table 2 .

Table 2: Composition of Tax Revenue (1974/75 to 2017/18)

\begin{tabular}{|c|c|c|c|c|c|c|}
\hline $\begin{array}{c}\text { Fiscal } \\
\text { Year }\end{array}$ & Total Tax & Customs & Excise & $\begin{array}{c}\text { Income } \\
\text { Tax }\end{array}$ & $\begin{array}{c}\text { sales tax } / \\
\text { VAT }\end{array}$ & $\begin{array}{c}\text { Other } \\
\text { Tax }\end{array}$ \\
\hline $1974 / 75$ & 841.7 & 328.5 & 119.7 & 47 & 206.7 & 139.8 \\
\hline $1975 / 76$ & 908.6 & 358.5 & 132.1 & 87.2 & 181.9 & 148.9 \\
\hline $1976 / 77$ & 1100.1 & 386.2 & 166.1 & 133.3 & 247.3 & 167.2 \\
\hline $1977 / 78$ & 1243.9 & 458.8 & 164.4 & 136.8 & 306.2 & 177.7 \\
\hline $1978 / 79$ & 1476.8 & 626.7 & 192.6 & 103 & 397.3 & 157.2 \\
\hline $1979 / 80$ & 1538.8 & 608 & 215.2 & 111.2 & 443.2 & 161.2 \\
\hline $1980 / 81$ & 2035.7 & 815.8 & 242.2 & 144 & 604 & 229.7 \\
\hline $1981 / 82$ & 2211.3 & 825.1 & 305.7 & 189.7 & 678.7 & 212.1 \\
\hline $1982 / 83$ & 2426.1 & 760.9 & 365.8 & 240.1 & 825.1 & 234.2 \\
\hline $1983 / 84$ & 2737 & 825.9 & 432.2 & 290.9 & 907.5 & 280.5 \\
\hline $1984 / 85$ & 3151.2 & 1064.5 & 483.9 & 307.3 & 1012.6 & 282.9 \\
\hline $1985 / 86$ & 3659.3 & 1231 & 558.7 & 364.4 & 1173 & 332.2 \\
\hline $1986 / 87$ & 4371.7 & 1505.1 & 678.6 & 437.5 & 1363 & 387.5 \\
\hline $1987 / 88$ & 5752.8 & 2214.6 & 825.3 & 579 & 1612.5 & 521.4 \\
\hline $1988 / 89$ & 6287.2 & 2289.9 & 877.7 & 861.1 & 1698.9 & 559.6 \\
\hline $1989 / 90$ & 7283.9 & 2684.9 & 1097 & 919 & 1953.8 & 629.2 \\
\hline $1990 / 91$ & 8176.3 & 3044.3 & 1200.2 & 746 & 2354.4 & 831.4 \\
\hline $1991 / 92$ & 9875.6 & 3358.9 & 1414.3 & 855.5 & 3283.6 & 963.3 \\
\hline $1992 / 93$ & 11662.5 & 3945 & 1452.8 & 1124.8 & 4007.7 & 1132.2 \\
\hline $1993 / 94$ & 15371.5 & 5255 & 1592.5 & 1824.5 & 5380.9 & 1318.6 \\
\hline $1994 / 95$ & 19660 & 7018.1 & 1657.3 & 2711.8 & 6857.1 & 1415.7 \\
\hline $1995 / 96$ & 21668 & 7327.4 & 1944.3 & 3311.6 & 7429.3 & 1655.4 \\
\hline $1996 / 97$ & 24424.3 & 8309.1 & 2298.1 & 3969 & 8162.9 & 1685.2 \\
\hline $1997 / 98$ & 25939.8 & 8502.2 & 2885.8 & 4685.9 & 8020.6 & 1845.3 \\
\hline $1998 / 99$ & 28752.9 & 9517.7 & 2953.2 & 5850.7 & 8765.9 & 1665.4 \\
\hline $1999 / 00$ & 33152.1 & 10813.3 & 3127.6 & 7006.2 & 10259.7 & 1945.3 \\
\hline
\end{tabular}




\begin{tabular}{|c|c|c|c|c|c|c|}
\hline $2000 / 01$ & 38865 & 12552.1 & 3771.2 & 8650.1 & 12382.4 & 1509.2 \\
\hline $2001 / 02$ & 39330.6 & 12650 & 3807 & 8436 & 12267.3 & 2170.3 \\
\hline $2002 / 03$ & 40896 & 12783.2 & 3771.2 & 8811.8 & 13459.7 & 2070.1 \\
\hline $2003 / 04$ & 48173 & 15554.8 & 6226.7 & 8512.5 & 14478.9 & 3400.1 \\
\hline $2004 / 05$ & 54104.7 & 15701.6 & 6445.9 & 9402.4 & 18885.4 & 3669.4 \\
\hline $2005 / 06$ & 57430.4 & 15344 & 6507.6 & 9598.8 & 21610.7 & 4369.3 \\
\hline $2006 / 07$ & 71126.7 & 16707.6 & 9343.2 & 13979.1 & 26095.6 & 5001.2 \\
\hline $2007 / 08$ & 85155.5 & 21062.4 & 11189.6 & 16223.3 & 29815.7 & 6864.5 \\
\hline $2008 / 09$ & 117051.9 & 26792.9 & 16220.9 & 23457.3 & 39700.9 & 10879.9 \\
\hline $2009 / 10$ & 159785.3 & 35218.9 & 24147.6 & 33821.3 & 54920.9 & 11676.6 \\
\hline $2010 / 11$ & 177227.2 & 35713.5 & 26338.5 & 41350.3 & 61663.6 & 12161.3 \\
\hline $2011 / 12$ & 211721.8 & 43390.6 & 30016.1 & 51303 & 70930.4 & 16081.7 \\
\hline $2012 / 13$ & 259610 & 56890 & 36660 & 67020 & 83510 & 15530 \\
\hline $2013 / 14$ & 311800 & 67880 & 45390 & 77920 & 100960 & 19650 \\
\hline $2014 / 15$ & 355942.9 & 74671 & 53525 & 88459.1 & 112377.4 & 26910.4 \\
\hline $2015 / 16$ & 421096.6 & 82159.1 & 65776.4 & 117407.8 & 122411.9 & 33341.4 \\
\hline $2016 / 17$ & 547486.4 & 113184 & 84678.4 & 148236.1 & 160316.6 & 41071.3 \\
\hline $2017 / 18$ & 659491.3 & 137785.3 & 102579.1 & 159900.5 & 206793.9 & 52432.6 \\
\hline
\end{tabular}

Source: Economic Survey, FY 2016/17 and various years' budget.

The sales tax/VAT, most important component of indirect taxes, also increased substantially during the period of study. The sales tax was only NRs. 206.7 million in FY 1974/75, but the Value-Added Tax (VAT) was Rs 206,793.9 million in FY 2017/18. The revenue from excise duties, on the other hand, increased from Rs.119.7 million in fiscal year 1974/75 to Rs. 102,579.1million in FY 2017/18. Due to the exclusion of imported goods from the excise net, and exclusion of most of the domestically produced goods from the excise net, after the implementation of VAT in 1997, the contribution is relatively small now.

Income tax rose from the amount of NRs. 47 million in FY 1974/75 to NRs.159,900.5 million in FY 2017/18. In the Nepalese tax structure, income tax was introduced in FY $1963 / 64$ when its contribution to total revenue was very low at 1.77 percent. Among the components of taxes, the contribution of custom duties was Rs.328.5 million in FY 1974/75 to NRs.137785.3 million in FY 2017/18.

\section{Conclusion}

Though the payment of tax is a moral obligation and tax payer is aware about the fact that revenue generated by government through taxes is used for the welfare of the society but due to high personal income tax rates and other irrationalities in prevailing 
tax constitution, the tax payer feel a bit pinched while contributing toward this noble cause. The existing Nepali tax system suffers from several limitations. The entire tax system for raising revenue is not working well. It lacks transparency and efficiency is widely and justifiably perceived to be unfair. Fixing the problems will require change in policies, laws, regulations and administrative procedures. Necessary policy changes should include the selection of appropriate taxes, while also

Addressing their structure and operation; administrative changes include the establishment of information and monitoring systems designed to reduce the possibility of arbitrary behavior by tax officials; and legal and administrative changes should be designed to align the incentives facing taxpayers and tax collectors with the goals of the tax system

\section{References}

Aaron, H. J. \& Munnell, A. H. (1992). 'Reassessing the Role for Wealth Transfer Taxes', National Tax Journal, 45, 119-43.

Cnosser, S. (1974). Revenue Aspects of Excise System. Washington, IMF, FAD.

Dahal, M. K.. (2004). 'Improving tax system in Nepal: Agenda for reforms'. In Madan Kumar Dahal (Ed.) Nepalese Economy: Towards Building a Strong Economic Nation-State. Kathmandu: CEDECON and New Hira Books Enterprises.

Gupta, A. (2009). The Trend and Responsiveness of Personal Income Tax in India. IGIDR Proceeding.

Haig, R. M. (1921). 'The Concept of Income'. In R. M. Haig (Ed.). New York City, The Federal Income Tax, Columbia University Press.

Hicks. S. J (November 1974). 'Real and monetary factors in economic fluctuations.' Scottish Journal of Political Economy. United Kingdom Vol. XXI, No. 3.

Johansson, A. et. al. (2008). Tax and Economic Growth (OECD Working Paper 620). United Kingdom, Economics Department. Organi-zation for Economic Cooperation and Development.

Kandel, P. R. (2011). Tax laws and tax planning in Nepal. Kathmandu: Benchmark Education Support Pvt.Ltd.

Kelly, S. R. (1999). 'Intergovernmental Revenue Allocation Theory and Application: Application to Nepal'. Asian Journal of Public Administration.

Ministry of Finance (Various Years). Economic Survey, Kathmandu: Ministry of Finance, Nepal Government.

Musgrave R. A. \& Musgrave, P. B. (1989). Public Finance in Theory and Practice (5th ed.). New York, McGraw Hill.

Mintz, J. (1995). 'The Corporation Tax: A Survey', Research Journal: Fiscal Studies, Medford: Institute for Fiscal Studies. Vol. 5, pp. 23-68.

Pechman, J. A. (1985). Who Paid the Taxes (1966-85). Washington DC: Brookings Institution.

Shah, R. K. (2012). Vat in Nepal, Kathmandu: Heritage publishers and Distributor Pvt. Ltd.

Simons, H. C. (1938). Personal Income Taxation, Chicago: Chicago University Press.

Shoup, C. S. (1969). Public Finance, New Brunswick: Aldine Transaction.

Whalley, J. (September, 1974). 'Estate Duty as a Voluntary Tax: Evidence from the Stamp Duty Statistics' Economic Journal Cowley Road Blackwell Publishing, Ltd.UK, Vol. 84. 
Sutherland, A. (1984). 'Capital Transfer Tax: Adieu' Research Journal: Fiscal Studies, Medford: Institute for Fiscal Studies. Vol. 5, pp. 68-83.

Nepal Government (2002). Income Tax Act, 2002 and Income Tax Rules, 2002, Kathmandu

Nepal Government (1996). Value Added Tax Act 1996 and Value Added Tax Rules 1996, Kathmandu: Nepal Government.

Nepal Government (2001). Excise Act 2001 and Excise Rules 2001, Kathmandu: Nepal Government.

Nepal Government (2062). Customs Act 1962 and Customs Rules 1962, Kathmandu: Nepal Government.

Retrieved (20 October 2018) from http://dx.doi.org/10.1787/241216205486.

Retrieved (2 November 2018) from http://www.imf.org

Retrieved (17 October 2018) from http://www.ird.gov.np

Retrieved (25 October 2018) from http://data.mof.gov.np

Retrieved (30 October 2018) from https://doi.org/10.1111/j.1467-9485.1974.tb00193.x 